\title{
Principals, School Library, SL Professionals, Learning Outcomes, Partnerships, SL Web Advocacy
}

\author{
Maria José Vitorino (Portugal)[1] \\ Teacher and Librarian \\ Portuguese School Libraries Network (RBE) Advisor[1] \\ Portuguese Librarian's Archivist's and Documentalist's Association \\ (BAD) Executive Board Member \\ THEKA Teacher's Training for SL Development Gulbenkian \\ Foundtion Project Coordenation Team Member
}

\begin{abstract}
:
Even within many different school leadership styles, it seems to be an evidence to many $S L$ professionals that Principal's role is always a key factor for SL services, curriculum enhancement and learning outcomes, valuing or, in the contrary, giving hard times to SL professionals projects and SL teamwork. School Principal's role is particulary important concerning teachers-SL cooperation, the very heart of learning success. How could each SL professional and each SL professional team learn to act wisely, improving communication and advocacy skills, managing strategies according to different School Principal's profiles and contexts? Which are School Principal's "valued" information sources on $S L$ issues - official, professional, networking, public librarians sources? And which, and how, could be reinforced, locally, nationally and internationally (IASL included)? Web 2.0 is making/could make/ should make a difference for these purposes?
\end{abstract}

Tags:

School Libraries, Networking, School Principals, Teacher librarians, School Librarians, Teamwork, SL Web resources, IASL

\section{Full Text:}

Even within many different school leadership styles, it seems to be an evidence to many SL professionals that Principal's role is always a key factor for SL services, curriculum enhancement and learning outcomes, valuing or, in the contrary, giving hard times to SL professionals projects and SL teamwork. School Principal's role is particulary important concerning teachers-SL cooperation, the very heart of learning success.

How could each SL professional and each SL professional team learn to act wisely, improving communication and advocacy skills, managing strategies according to different School Principal's profiles and contexts?

Improving school libraries staff's management and communication skills by professional training is important, but it is not enough. Project management and development skills are essential, and SL professionals must be able to argue on educational an school management "language". They need to be able to understand and debate different educational and school visions and political options, in order to be accepted by School Principals as well as by all school staff members. Curriculum knowledge is essential, teacher training - including some real classroom teaching experience - as well as librarian training are important. Helping each one of us in our SL daily problems and solutions, through professional networking, as in Communities of Practice,connecting professionals locally or globally, could be a powerful 
answer, mainly if Principals recognise it as a major helping factor. We must present the "connected SL professional"as a stronger and wiser professional, as well as a reinforced value for Learning Resources, and the school role.

Which are School Principal's "valued" information sources on SL issues - official, professional, networking, public librarians sources? And which, and how, could be reinforced, locally, nationally and internationally (IASL included)?

There are still many School Principals with lack of information on school libraries and their actual standards. During Principals professional training (when it occurs) it would be very important to include SL approach, including IFLA/Unesco and IASL guidelines and framework.

Recent research on SL and students educational success is relevant unfortunately, this research results are mainly available in English language. We need more national/local researchers and universities willing to develop and support it! So, it is important to improve this kind of studies available through repositorium usually recognised by School Management researchers and trainers, and by teachers - Portuguese Minho University Repositorium, and E-LIS, are some good examples. We need to know them and use it, increasing the SL research information quality. SL cooperation with all classroom teachers in daily basis is crucial, as well as a good communication with each Principal and Education Local/Regional Authorities, and SL profesional knowledge on research contents and trends.

In many countries, SL official standards and other SL official documents are very important. All Principals value them, even in private schools, specially if SL quality evidences are officially recognised as evidences for good school management. Therefore, those evidences will value Principals professional curriculum. At the same time, all SL data benefits, if properly considered, school official evaluation, and, of course, Community image that school role. So, SL work with local communities, including "social" activities are as important as cooperation with teachers. In many communities, public libraries are valued by families, and it is a good thing to show a good connection SLPL. SL professionals must be in touch with families and Community leaders. We must work on social integration issues (remember IFLA/UNesco SL and PL vision!) as well on reading promotion and curriculum SL role. Our students belong to those communities, and they are expected to be able to create new ones, themselves, in the future, during school years and throughout all life.

Awards and good media news could be very useful, but web 2.0 resources are opening a new field IASL and national Associations must be aware of:

- social networking and local/national language contents on SL, from the SL professional point of vue, but also from other points of vue:

principal's, classroom teacher's, families, community leaders, opinion makers (including local press)

local training on SL global and national standards and guidelines, including projects for and with Principals

support for research and web good information resources, with good access and significant content available through web search tools 


\section{lobbying for official measures supporting SL value on each School evaluation for public as well as private institutions}

Web 2.0 is making/could make/should make a difference for these purposes? Web 2.0 can save us time and money if we learn how to use it, as long as we do not give up everything else... SL should continue to be a real meeting place, as well as a virtual resource media.

SL digital front are an imperative, an SL professionals are aware of that, as we can see through blogs, websites, and others. However, many and many SL do not use it, yet. We must learn how to improve the ways we use it, and also how to avoid to be used by content providers with non educational priorities (commercial, political, etc). New tools and new possibilities still require old wisdom and improved knowledge.

School Principals are using Web 2.0, but in many countries they show high competitiveness among themselves. So, we must be aware of this. Each country, each language territory and each local reality present different landscape regarding Web 2.0. However, this domain is growing, and growing fast - it is an educational challenge we need to keep up to.

IASL should make the difference, reinforcing web resources, translation resources, project approach support and networking strategies, keeping technology updated as well as our mainframe basis (IASL Statement), and partnership connections with Associations and Institutions, specially with IFLA and National School Librarians and Public Librarians Associations, among others.

Abano, 38th IASL Annual Conference, September 2009

[1] Working in Portuguese School Libraries Network, supporting school libraries development and partnerships (specially with public libraries). mariajosevitorino@gmail.com 